\title{
Visitation patterns of jaguars Panthera onca (Carnivora: Felidae) to isolated water ponds in a tropical forest landscape
}

\author{
Carlos A. Gaitán ${ }^{1 *}$, Vivian R. González-Castilloํ, Gerber D. Guzmán-Flores ${ }^{1}$ Andrea L. Aguilera ${ }^{1}$, and Manolo J. García ${ }^{1}$ \\ ${ }^{1}$ Centro de Estudios Conservacionistas, Facultad de Ciencias Químicas y Farmacia, Universidad de San Carlos de Guatemala, \\ Avenida la Reforma, 0-63 zona 10, Ciudad de Guatemala 01010, Guatemala. E-mail: gaitan.carlos@usac.edu.gt (CAG), gonzalez. \\ vivian@usac.edu.gt (VRG-C), guzman.gerber@usac.edu.gt (GDG-F), aguilera.andrea@usac.edu.gt (ALA), garcia.manolo@usac. \\ edu.gt (MJG). \\ ${ }^{*}$ Corresponding author
}

Jaguar populations have declined dramatically in the last century. The Maya Biosphere Reserve (MBR) within the Selva Maya (SM) is a priority area for jaguar conservation. Influential factors in the jaguar seasonal distribution include the availability of surface water in wetlands such as the "aguadas" and the availability of prey. Aguadas are formed by isolated depressions in the landscape and serve as a water supply for wildlife during dry periods. The goal of this study was to describe the visitation patterns of jaguars to aguadas in a Tropical forest at Dos Lagunas Protected Biotopo, a core zone of the MBR, Guatemala. We used camera-trap data from seven aguadas during the dry seasons 20142017. We determined visitation rates (VR, records for 1,000 trap-days) and activity patterns (AP) of jaguars for all years, aguadas, and sexes. We tested for significant differences in AP between sexes, and we estimated the coefficient of overlap (D) for female and male jaguar activity. We recorded 14 individuals (five females, eight males, and one unsexed) in 60 visit events. Jaguars have significant more diurnal activity at aguadas, and showed a $V R=13.1$ for 1,000 trap-days. VR varied between aguadas (VR $=9.5-19.4)$, years $(V R=1.9-39.2)$ and sexes $(V R=6.1$ for females and 5.5 for males). We did not find significant differences in the AP of female and male jaguars $(P>0.05)$. The coefficient of overlap between activity of females and males was $D=0.77$ (95\% confidence interval: 0.70 to $0.84 ; P>0.05$ ). Aguadas may represent regular sites of jaguar home-ranges overlap for the important resources they provide for wildlife during the dry season. Aguadas could play an important role in the conservation and management of jaguar populations since the spatial distribution of these bodies of water is scattered, but ecologically important for jaguars within the MBR and the SM. Aguadas also, are important landscape features that could influence the spatial interactions of individuals. We encourage jaguar researchers to increase investigation on jaguars visiting aguadas and other wetlands in the SM to better understand the jaguar activity patterns and sex-specific habitat requirements.

Las poblaciones de jaguares disminuyeron drásticamente en el último siglo. La Reserva de la Biosfera Maya (RBM), en la Selva Maya (SM) es un área prioritaria para su conservación. Entre los factores que afectan su distribución estacional están la disponibilidad de agua en humedales como las aguadas, y la disponibilidad de presas. Las aguadas son formadas por depresiones en el paisaje y sirven de abastecimiento de agua para la fauna silvestre. El objetivo de este estudio fue describir los patrones de visita de jaguares a las aguadas en un bosque tropical en el Biotopo Protegido Dos Lagunas, una zona núcleo de la RBM, Guatemala. Se emplearon datos de trampas-cámara en siete aguadas durante las épocas secas 2014-2017. Se determinaron tasas de visita (TV, registros por 1,000 días-trampa) y patrones de actividad (PA) de jaguares por todos los años, aguadas y sexos. Se evaluaron diferencias significativas en los PA de ambos sexos, y se estimó el coeficiente de traslape (D) en los patrones de actividad de hembras y machos. Se registraron 14 individuos (cinco hembras, ocho machos, uno indeterminado) en 60 eventos independientes. Los jaguares se catalogaron con mayor actividad diurna, presentando una TV = 13.1 eventos por 1,000 días-trampa. Las TV variaron entre aguadas (TV = 9.5 - 19.4), años (TV = 1.9 - 39.2) y sexos. Las hembras presentaron una mayor TV en comparación a los machos ( $T V=6.1$ y 5.5 , respectivamente). No se encontraron diferencias significativas en la actividad de ambos sexos, con un nivel de traslape de $D$ $=0.77$ (95\% de intervalo de confianza: 0.70 a 0.84; $P>0.05$ ). Las aguadas podrían representar sitios de traslape en los ámbitos hogareños de los jaguares, debido a su importancia como recurso vital durante la época seca. Además, las aguadas pueden ejercer un importante rol en la conservación y manejo de poblaciones de jaguares debido a su distribución aislada, pero ecológicamente importante, que influye en las interacciones espaciales de los individuos. Recomendamos incrementar la investigación en jaguares y sus visitas a las aguadas y otros humedales para una mejor comprensión de sus patrones de actividad y requerimientos del hábitat específicos para ambos sexos.

Keywords: Aguadas; camera-traps; habitat use; overlap; Selva Maya.

(c) 2021 Asociación Mexicana de Mastozoología, www.mastozoologiamexicana.org

\section{Introduction}

Jaguars Panthera onca (Linnaeus, 1758) are the largest cats in the Americas. In the northern hemisphere, their main populations are distributed in the north and south of Mexico (for example in Sonora and in the Sierra Madre de (hiapas), as well as in the north of Guatemala and Belize. In South America, the most important populations are located in the Brazilian Pantanal and in the Amazon rainforest of Colombia, Ecuador, Peru, Venezuela, Bolivia, and Brazil (Isasi-Catalá 2013; Payán et al. 2013; Espinosa et al. 2016; Maffei et al. 2016; De la Torre et al. 2017, 2019). Jaguars are top predators and therefore play a fundamental role in the dynamics of the ecosystems in which they live (Seymour 1989; Currier 1983). Specifically, jaguars contribute significantly in the top-down regulation of Neotropical food chains, because they regulate the abundance of secondary and primary consumers, which, in turn, regulates the abundance of producers, modifying the complete species assemblage in the ecosystems where they occur (Estes et al. 2011). 
Because the jaguar is a species of Neotropical affinity that prefers dense forest environments with high levels of humidity, its populations have decreased dramatically in some of the driest areas of its distribution (southeastern United States, eastern Brazil and the plains of Argentina; De Azevedo et al. 2016; Di Bitetti et al. 2016; Pereira-Garbero and Sappa 2016). Currently, the Selva Maya (SM), located in the north of Mesoamerica (southeast of Mexico, north of Guatemala and northwest of Belize) is one of the highest priority jaguar conservation areas since it harbors the second largest population in the continent. In Guatemala, The Maya Biosphere Reserve (MBR) is the highest priority area for conservation of jaguars. The SM which includes the MBR has been identified as a Jaguar Conservation Unit (JCU), which means is one of the most important areas for jaguar conservation and that includes strict protection zones (Zeller 2007; García-Anleu et al. 2016; De la Torre et al. 2016, 2017; Jędrzejewski et al. 2018).

In the MBR, the aguadas are water ponds supplied with rainwater which are formed by isolated depressions on the land in which the soil is clayey and compact (Reyes 2009; Reyna-Hurtado et al. 2010; García et al. 2018). The aguadas provide a valuable resource for a variety of wildlife species, particularly during the dry season (Reyna-Hurtado et al. 2010; García et al. 2018). For predators such as jaguars, the aguadas represent a determining factor for home-range delineation, because in addition to providing drinking water, they favors the seasonal aggregation of prey that also visit these bodies of water (Muckenhirm and Eisenberg 1973; Núñez et al. 2002; Simá et al. 2008).

Home-ranges of female and male jaguars are different (Sunquist and Sunquist 2002). Females generally occupy home-ranges which include a sufficient number of prey for themselves and their cubs, while males occupy larger home-ranges, maximizing access to females and maintaining sufficient prey for individual survival (Schaller and Crawshaw 1980). As a consequence, the home-range of a single male jaguar is occupied by the home-ranges of several females (Astate et al. 2008; Morato et al. 2016; McBride and Thompson 2018).

The availability of surface water and the abundance and availability of prey are factors that largely determine the patterns of habitat use by jaguars (Sunquist 1981; Mizutani and Jewell 1998; Scognamillo et al. 2002; Figel et al. 2019; Rabelo et al. 2019). In most of the MBR and the SM, the availability of surface water during the dry season is mostly restricted to the aguadas. In this study, we described the patterns of visitation to aguadas by jaguars in the Dos Lagunas Protected Biotopo (DLPB), a core zone of the MBR, through visitation rates (VR) and activity patterns (AP) during the dry season.

\section{Material and Methods}

Study site. The DLPB, located in the extreme north of Guatemala, has an extension of $307 \mathrm{~km} 2$. It borders the MiradorRío Azul National Park in the east and west, the Calakmul
Biosphere Reserve in Mexico to the north, and the Multiple-use Zone of the MBR to the south. It is one of the protected areas with least human impact in Guatemala and is considered part of the "Heart of the Selva Maya" (CONAP 2015; Veras 2009). The DLPB is characterized, like the rest of the MBR and the SM, by karstic and permeable soils which result in an underground drainage. The lower areas of the forest have the highest percentage of clayey soil and less permeability, favoring the formation of water ponds that store rainwater such as the aguadas (Araujo 2014; Veras 2009; Reyna-Hurtado et al. 2010; García et al. 2018).

Aguadas are usually found in low densities; they are scattered in the landscape and can vary in size, ranging from 236 $\mathrm{m}^{2}$ to several hectares (González 2015; Reyna-Hurtado et al. 2010). Since the aguadas are formed by the accumulation of rainwater, their dynamics is strongly associated with the intensity and duration of the dry and rainy season of each year. Some aguadas can remain filled through the year, and some tend to dry out completely during the dry season (González 2015). Due to the low availability of surface water in the region, the aguadas are one of the main sources of water for wildlife during dry periods, especially where large bodies of water are non-existent and humidity is low (Simá et al. 2008; Reyna-Hurtado et al. 2010; García et al. 2018).

Camera-trapping. Photographs obtained from the San Carlos University of Guatemala (Usac), Centro de Estudios Conservacionistas (Cecon) and the Central American Tapir Monitoring Program of the Defensores de la Naturaleza Foundation (FDN) were used to register jaguar activity in the aguadas of the DLPB. We monitored seven aguadas by setting up Bushnell ${ }^{\circledR}$ Trophycam camera-traps during the 2014 and 2015 dry seasons, programed to take three photographs per capture event and a 15 seconds interval between capture events; and setting up Bushnell ${ }^{\oplus}$ Trophycam Agressor No Glow camera-traps during dry season 2016 and 2017, programmed to take one photograph per capture event with a one second interval between capture events. The number of aguadas sampled and camera-traps used varied according to the year of sampling: 2 aguadas and 6 cameras in 2014; 3 aguadas and 9 cameras in 2015; six aguadas and 17 cameras in 2016; and, six aguadas and 10 cameras in 2017. Total sampling effort was 4,587 trap-days (Tables 1 and 2; Figure 1).

Table 1. Characteristics of aguadas from Dos Lagunas Protected Biotopo, Maya Biosphere Reserve, Guatemala.

\begin{tabular}{lllr}
\hline Aguada & Seasonality & Forest type & $\begin{array}{c}\text { Distance to nearest aguada } \\
(\mathbf{k m})\end{array}$ \\
\hline A1 & Seasonal & Tall & $4.9(\mathrm{A6})$ \\
A2 & Seasonal & Tall & $1.7(\mathrm{~A} 7)$ \\
A3 & Permanent & Tall & $3.2(\mathrm{~A} 4)$ \\
A4 & Permanent & Tall & $3.2(\mathrm{~A} 3)$ \\
A5 & Permanent & Short & $5.3(\mathrm{~A} 1)$ \\
A6 & Permanent & Short & $4.9(\mathrm{~A} 1)$ \\
A7 & Seasonal & Short & $1.7(\mathrm{~A} 2)$ \\
\hline
\end{tabular}




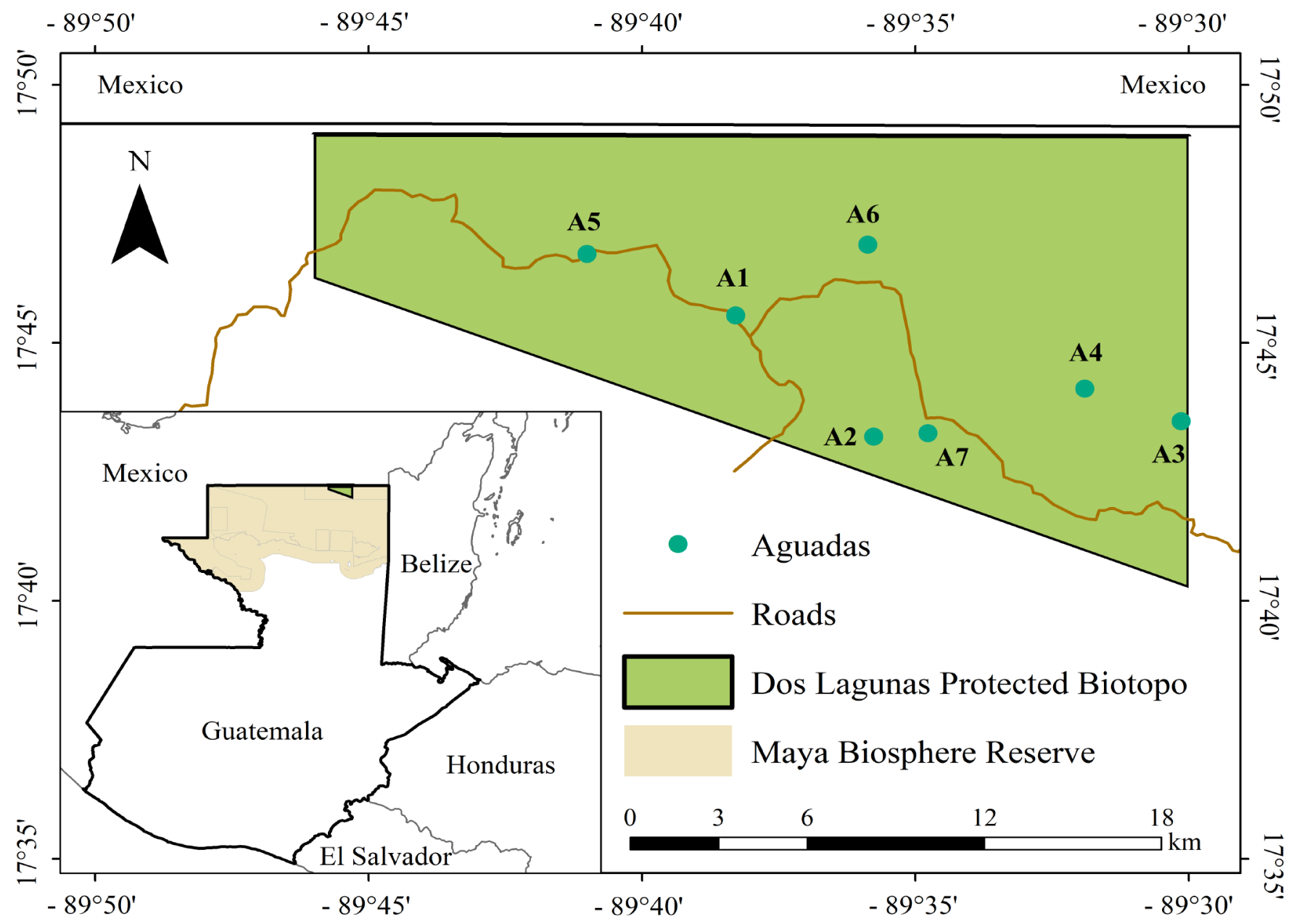

Figure 1. Location of aguadas of the Dos Lagunas Protected Biotopo, Maya Biosphere Reserve, Guatemala.

We used Camera Base version 1.7 software (Tobler 2015) to process photographs and organize them in a database with the following information: site, date, time, cameratrap station (aguada), sex and age of individuals. We identified individuals by comparing rosette patterns of the coat (Karanth and Nichols 1998). Each capture event was considered independent of another capture event if 1 hour elapsed between capture events of the same individual in the same aguada.

Visitation rates (VR). To account for differences in sampling effort, we determined visitation rates (VR) of jaguars (for females, for males, and both) using the following equation: $\mathrm{VR}=(\mathrm{N} / \mathrm{SE}) \times 1,000$ trap-days $[\mathrm{N}=$ number of independent captures, and $\mathrm{SE}=$ sampling effort measured as the number of days multiplied by the number of camera-traps in each aguada]. We calculated VR for each aguada and for all aguadas combined.

Activity patterns (AP). The activity pattern of each jaguar was classified as diurnal, nocturnal or crepuscular activity. The initial time of each visit event was used to determine these visiting patterns. Capture events recorded from one hour after dawn (sunrise) to one hour before dusk (sunset) were considered as diurnal; events recorded between one hour after dusk to one hour before dawn were con- sidered as nocturnal; and, events recorded between one hour before dawn and one hour after dawn, and between one hour before dusk and one hour after dusk were classified as crepuscular (Monroy-Vilchis et al. 2011; Jiménez et al. 2010). The time of sunrise and sunset for each day was determined using the solar calculator from the Global Monitoring Division of the Eastern System Research Laboratory of the National Oceanic and Atmospheric Administration of the U. S. Department of Commerce (NOAA 2014).

We used the methodology of Jiménez et al. (2010) to determine the AP of jaguars in aguadas: "diurnal" when $<10 \%$ of events were recorded at night; nocturnal when $>90 \%$ of the visit events were recorded at night; "mostly diurnal" when night time events ranged between 10 to 30 $\%$; "mostly nocturnal" when 70 to $90 \%$ of the events were recorded at night; "crepuscular" when $50 \%$ or more of the events were during twilight periods; and "catameral" when events occurred sporadically during the day and night.

Activity and overlap models. We tested for significant differences $(P<0.05)$ in AP between sexes fitting kernel density models to estimate and compare female and male jaguar activity distributions using a Wald test (tested on chi square distribution with one degree of freedom), and quantified and compared levels of activity for both sexes 
Table 2. Sampling effort in aguadas. *1 Camera deactivated from March 15 to May 31 2015; *2 Camera deactivated from May 7 to May 312015.

\begin{tabular}{|c|c|c|c|c|c|c|c|c|}
\hline Year & Aguada & Cameras & First & Last & Days & No Cameras & Effort & Total \\
\hline \multirow[t]{2}{*}{2014} & $A 3$ & All & $10 / 04 / 2014$ & $20 / 06 / 2014$ & 71 & 3 & 213 & 420 \\
\hline & A6 & All & $11 / 04 / 2014$ & $19 / 06 / 2014$ & 69 & 3 & 207 & \\
\hline \multirow[t]{5}{*}{2015} & A3 & All & $26 / 04 / 2015$ & 06/07/2015 & 71 & 3 & 213 & 567 \\
\hline & A6 & All & $25 / 04 / 2015$ & $01 / 07 / 2015$ & 67 & 3 & 201 & \\
\hline & $\mathrm{A} 2$ & Camera 1 & $27 / 04 / 2015$ & $01 / 07 / 2015$ & 65 & 1 & 65 & \\
\hline & & Camera $2^{* 1}$ & $27 / 04 / 2015$ & $01 / 07 / 2015$ & 48 & 1 & 48 & \\
\hline & & Camera $3^{* 2}$ & $27 / 04 / 2015$ & $01 / 07 / 2015$ & 40 & 1 & 40 & \\
\hline \multirow[t]{9}{*}{2016} & $\mathrm{~A} 3$ & All & $5 / 04 / 2016$ & $30 / 08 / 2016$ & 147 & 4 & 588 & 2,319 \\
\hline & A6 & Cameras 1-3 & $06 / 04 / 2016$ & $27 / 08 / 2016$ & 143 & 3 & 429 & \\
\hline & & Camera 4 & $12 / 05 / 2016$ & $10 / 08 / 2016$ & 90 & 1 & 90 & \\
\hline & A5 & Cameras 1-2 & $06 / 04 / 2016$ & $23 / 08 / 2016$ & 139 & 2 & 278 & \\
\hline & & Camera 3 & $11 / 05 / 2016$ & $23 / 08 / 2016$ & 104 & 1 & 104 & \\
\hline & A4 & All & $5 / 04 / 2016$ & $29 / 08 / 2016$ & 146 & 3 & 438 & \\
\hline & $\mathrm{A} 1$ & Camera 1 & $11 / 05 / 2016$ & $23 / 08 / 2016$ & 104 & 1 & 104 & \\
\hline & A7 & Cameras 1-2 & $12 / 05 / 2016$ & $27 / 08 / 2016$ & 107 & 2 & 214 & \\
\hline & & Camera 3 & $12 / 05 / 2016$ & $25 / 07 / 2016$ & 74 & 1 & 74 & \\
\hline \multirow[t]{8}{*}{2017} & $\mathrm{~A} 3$ & Camera 1 & $30 / 03 / 2017$ & $19 / 06 / 2017$ & 81 & 1 & 81 & 1,281 \\
\hline & & Camera 2 & $30 / 03 / 2017$ & $10 / 08 / 2017$ & 133 & 1 & 133 & \\
\hline & & Camera 3 & $30 / 03 / 2017$ & $12 / 08 / 2017$ & 135 & 1 & 135 & \\
\hline & A6 & All & $29 / 03 / 2017$ & $10 / 08 / 2017$ & 134 & 3 & 402 & \\
\hline & A5 & Camera 1 & $29 / 03 / 2017$ & $10 / 08 / 2017$ & 134 & 1 & 134 & \\
\hline & A4 & Camera 1 & $30 / 03 / 2017$ & $5 / 08 / 2017$ & 128 & 1 & 128 & \\
\hline & $\mathrm{A} 1$ & Camera 1 & $29 / 03 / 2017$ & $10 / 08 / 2017$ & 134 & 1 & 134 & \\
\hline & A7 & Camera 1 & $29 / 03 / 2017$ & $10 / 08 / 2017$ & 134 & 1 & 134 & \\
\hline Total & & & & & & & & 4,587 \\
\hline
\end{tabular}

through bootstrapping (10,000 replicates) employing the package 'Activity' (Rowcliffe 2019) in software R (R Core Team 2020, $R$ version 3.6.3). We estimated the coefficient of overlap ( $D=$ level of overlap) for female and male jaguar activity, and we fitted kernel density models to compare AP between sexes by using the capture events in each aguada employing the package 'Overlap' (Meredith and Ridout 2020) in software $R$ (R Core Team 2020, $R$ version 3.6.3). We estimated the confidence intervals $(\mathrm{Cl})$ between lower and upper $95 \%$ limits in estimates of female and male activity overlap, calculated as percentile intervals from 10,000 boot- strap samples (Ridout and Linkie 2009). We plotted models not extended (extend = NULL, Meredith and Ridout 2020).

\section{Results}

We obtained 409 photographs of jaguars corresponding to 60 independent visit events in the seven sampled aguadas ( $\mathrm{A} 1$ to A7). Aguadas A3, A4 and A6, were the most frequented by jaguars (Table 3 ). We identified 14 individuals (eight males, five females and one of unknown sex) in 54 events $(90 \%)$ across five aguadas. At two aguadas we recorded six events (10\%) of individuals who could not be identified or sexed (Table 4).

Table 3. Visitation rates (VR) of jaguars by aguada, year and sex. F: Females, M: Males.

\begin{tabular}{|c|c|c|c|c|c|}
\hline Aguada & $2014(F, M)$ & $2015(F, M)$ & $2016(F, M)$ & $2017(F, M)$ & All years $(F, M)$ \\
\hline A1 & & & $9.6(0,0)$ & $0(0,0)$ & $4.2(0,0)$ \\
\hline$A 2$ & & $39.2(0,39.2)$ & & & $39.2(0,39.2)$ \\
\hline A3 & $9.4(4.7,4.7)$ & $18.8(0,18.8)$ & $6.8(5.1,0)$ & $17.2(14.3,0)$ & $11.7(6.6,3.7)$ \\
\hline A4 & & & $27.4(20.5,6.8)$ & $23.4(15.6,0)$ & $26.5(19.4,5.3)$ \\
\hline A5 & & & $0(0,0)$ & $7.5(0,0)$ & $1.9(0,0)$ \\
\hline A6 & $19.3(9.7,4.8)$ & $5.0(5.0,0)$ & $3.9(1.9,1.9)$ & $22.4(5.0,17.4)$ & $12.0(4.5,6.8)$ \\
\hline A7 & & & $10.4(0,6.9)$ & $14.9(14.9,0)$ & $11.8(4.7,4.7)$ \\
\hline All aguadas & $14.3(7.1,4.8)$ & $19.4(1.8,17.6)$ & $9.5(5.6,2.6)$ & $16.4(8.6,19.5)$ & $13.1(6.1,5.5)$ \\
\hline
\end{tabular}


From the 54 visit events with identified individuals, 17 (31.5\%) belonged to a single female; the rest of individuals were observed on one ( 2 individuals), two ( 3 individuals), three (4 individuals) or four (4 individuals) visit events (Table 4). The aguadas with the highest number of visit events with identified individuals were A6 with 16 (19.6 $\%), A 3$ and A4 with 13 each (48.1\%), A2 with six (11.1\%) and A7 with four visit events (7.4\%; Table 4). The aguadas with the highest number of visit events in a single year of study (of the 60 total events) were A4 (2016) and A6 (2017), with 12 and 9 events respectively, which represent $35 \%$ of visit events from all the study (Table 3 ). The aguadas visited by the highest number of individuals were $A 6$ ( 3 females, 4 males, 1 of unknown sex), A4 (5 females, 2 males, 1 of unknown sex), and A3 (3 females, 3 males, 2 of unknown sex), registering 8 individuals each.

Visitation rates (VR). We estimated a VR of 13.1 records for 1,000 trap-days for jaguars in all aguadas and all years (Table 4). However, VR varied among individual aguadas (VR $=1.9$ to 39.2 records for 1,000 trap-days) and years (VR $=9.5$ to 19.4 records for 1,000 trap-days), both for all jaguars combined and separately for females and males. We did not record visit events in aguadas A1 in 2017 and A5 in 2016 (VR $=0$ records for 1,000 trap-days), while in aguadas A2 in 2015 and A4 in 2016 we determined the highest values, $V R=39.2$ and $V R=27.4$ records for 1,000 trap-days, respectively. Females showed higher VR in aguadas than males (VR $=6.1$ and 5.5 records for 1,000 trap-days, respectively), with variation according to the years and the aguadas sampled (Table 3 ).

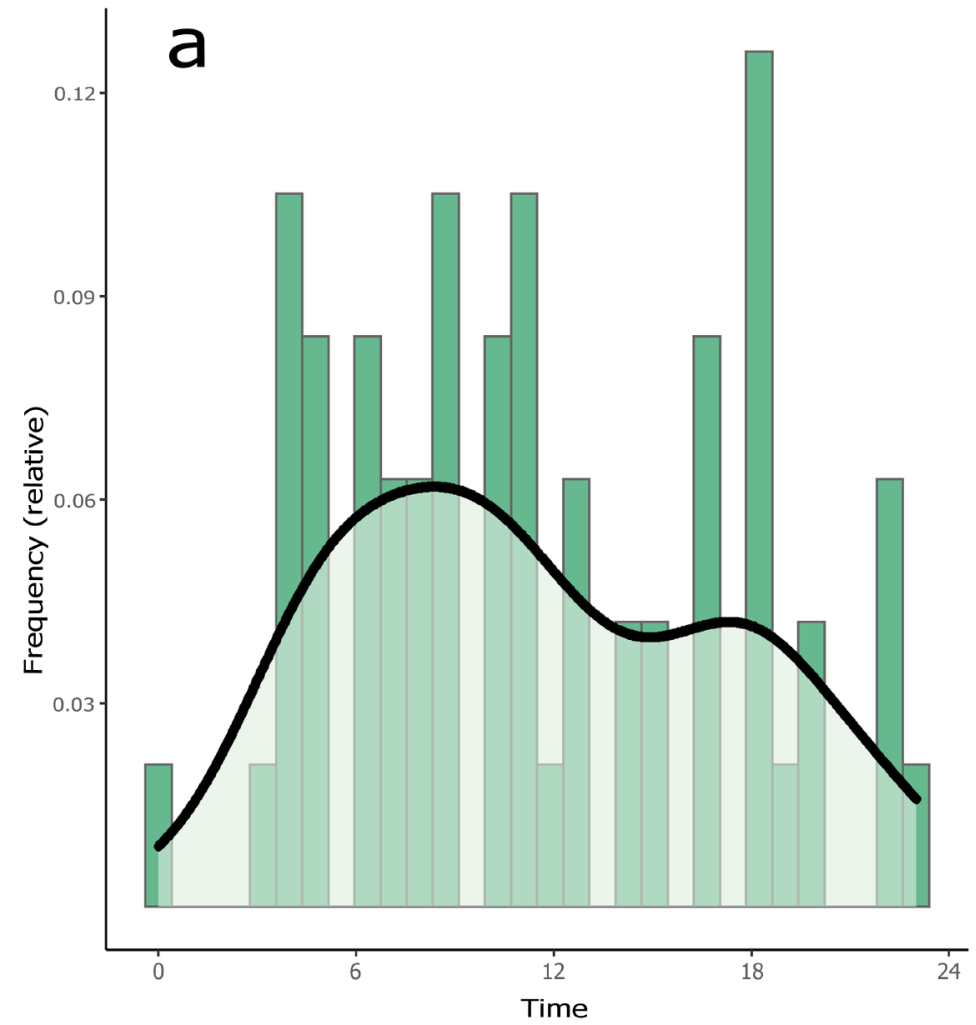

Activity patterns (AP). Jaguars presented a bimodal activity pattern, showing two peaks that occurred at midmorning, and before dusk. Across all years, jaguars showed more frequency of visits (independent events) from 18:00 to $18: 59 \mathrm{~h}$. However, we recorded the highest density of events between 04:00 to 11:59 h (before dawn to before noon), which represented the highest peak of activity of jaguars in aguadas (Figure 2a).

From the 60 total visit events, 30 (50\%) corresponded to diurnal activity (19 for females, 8 for males and 3 of unknown sex and identity), 10 (16.7\%) to nocturnal activity ( 2 for a female, 7 for males and 1 of unknown sex and identity) and 20 (33.3\%) to crepuscular activity (7 for females, 10 for males and 3 of unknown sex and identity). Females showed greater diurnal activity (19 events) compared to nocturnal ( 2 events) and crepuscular activity ( 7 events); while males showed 8,7 and 10 events for diurnal, nocturnal and crepuscular activity events, respectively (Figure 2b). Females showed a unimodal distribution, visiting aguadas during the day (after dawn and before dusk), while males showed a trimodal distribution, with their maximum peak at mid-morning, and two smaller peaks after dusk, and at midafternoon (Figure 3a). During night (after dusk and before dawn), females showed a bimodal distribution with similar peaks after 20:00 $\mathrm{h}$ and before midnight, while nocturnal activity of males was increasing until reaching their peak before dawn twilight (Figure 3b). In the case of twilight periods (crepuscular activity), females and males showed different and similar activity through dawn and dusk, respectively. During dawn twilight, females showed a bimodal

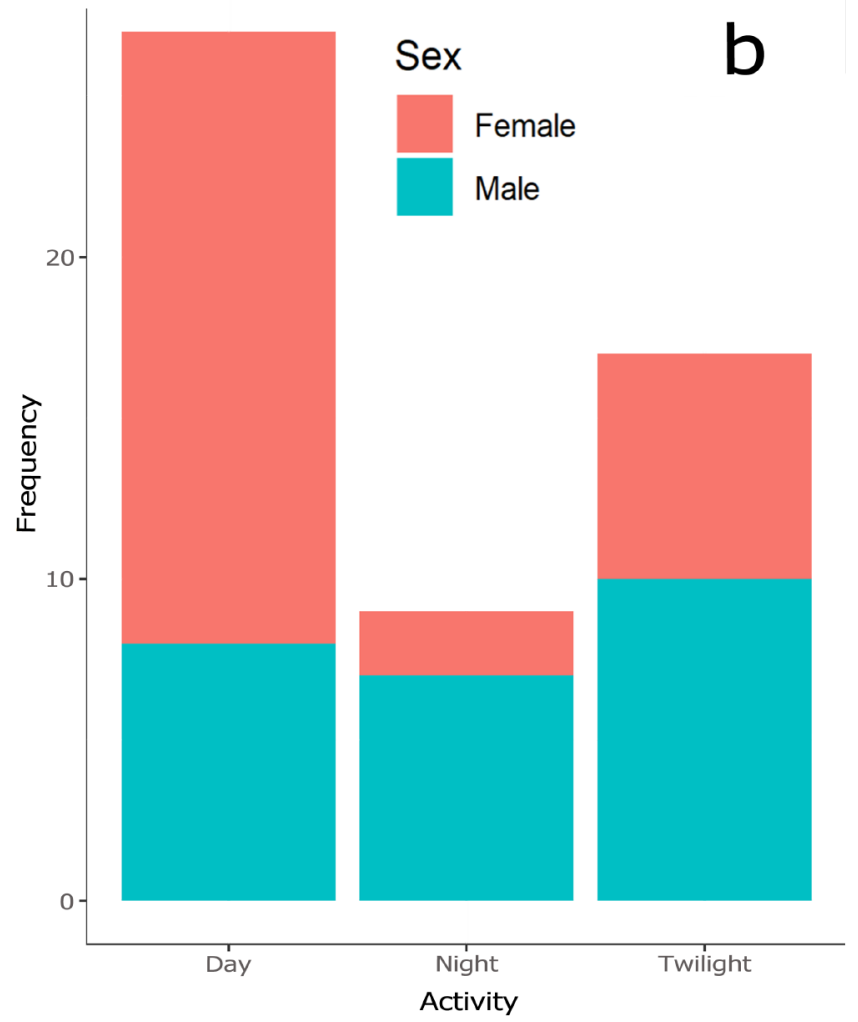

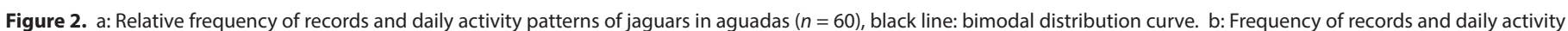

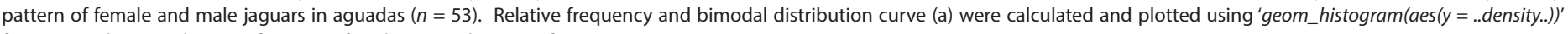
function and 'geom_density ()' function of package 'Ggplot2' in software R. 
Table 4. Jaguar individuals visit events in aguadas of the Dos Lagunas Protected Biotopo, Maya Biosphere Reserve, Guatemala. F: Female; M: Male; U: Unknown sex.

\begin{tabular}{|c|c|c|c|c|c|c|c|c|c|c|c|c|c|c|c|c|}
\hline & uada & F1 & F2 & F3 & F4 & F5 & U6 & M7 & M8 & M9 & M10 & M11 & M12 & M13 & M14 & Total \\
\hline \multirow[t]{3}{*}{2014} & $\mathrm{~A} 3$ & 1 & & & & & & & 1 & & & & & & & \\
\hline & A6 & 2 & & & & & 1 & 1 & & & & & & & & \\
\hline & & 3 & & & & & 1 & 1 & 1 & & & & & & & 6 \\
\hline \multirow[t]{4}{*}{2015} & $\mathrm{~A} 2$ & & & & & & & & 3 & 2 & 1 & & & & & \\
\hline & $\mathrm{A} 3$ & & & & & & & 2 & & & 2 & & & & & \\
\hline & A6 & & 1 & & & & & & & & & & & & & \\
\hline & & & 1 & & & & & 2 & 3 & 2 & 3 & & & & & 11 \\
\hline \multirow[t]{5}{*}{2016} & $\mathrm{~A} 3$ & 2 & & & 1 & & & & & & & & & & & \\
\hline & A4 & 4 & 2 & 2 & & 1 & & & & 2 & & 1 & & & & \\
\hline & A6 & & & 1 & & & & & & & & 1 & & & & \\
\hline & A7 & & & & & & & & & 1 & & & 1 & & & \\
\hline & & 6 & 2 & 3 & 1 & 1 & & & & 3 & & 2 & 1 & & & 19 \\
\hline \multirow[t]{5}{*}{2017} & $\mathrm{~A} 3$ & 4 & & & & 1 & & & & & & & & & & \\
\hline & A4 & & & 1 & 1 & & & & & & & & & & & \\
\hline & A6 & 2 & & & & & & & & & & & & 3 & 4 & \\
\hline & A7 & 2 & & & & & & & & & & & & & & \\
\hline & & 8 & & 1 & 1 & 1 & & & & & & & & 3 & 4 & 18 \\
\hline Total & & 17 & 3 & 4 & 2 & 2 & 1 & 3 & 4 & 5 & 3 & 2 & 1 & 3 & 4 & 54 \\
\hline
\end{tabular}

distribution in a very short period of time (two events at 05:37 and 05:39 h, respectively), while males increased their activity throughout dawn twilight (Figure 3c). During dusk twilight, females showed a trimodal distribution, with their maximum peak at 18:00 to 18:10 h, while males showed a bimodal distribution with their maximum peak at 18:30 to $18: 45 \mathrm{~h}$ (Figure $3 \mathrm{~d}$ ). Only $16 \%$ of all visit events were recorded at night hours, while $50 \%$ were recorded at daytime, classifying jaguar activity as diurnal in aguadas.

Activity and overlap models. Despite the observed differences in peaks, overall female and male jaguars did not show significant differences in their activity $(P>0.05$; standard error $=0.13$; Wald statistics estimate $=0.019$ ). The estimates for observed coefficient of overlap $(D=0.65)$ and the mean coefficient of overlap between female and male jaguar activity ( $D=0.77,95 \%$ confidence interval: 0.70 to $0.84)$, showed no significant difference between sexes in their activity $(P>0.05$, Figure 4$)$.

\section{Discussion}

The observed patterns suggest that female and male homeranges overlap in the aguadas, with variation in the number of individuals and visit events among sites and years. For females, the recurrent use of aguadas in different years suggests a certain degree of site fidelity as reported by Cavalcanti and Gese (2009) in Brazil, where home-ranges were maintained up to $90 \%$ for the second season, but changed the areas used more intensively. The five female individuals identified in this study were recorded in three of the seven aguadas sampled, exhibiting a high degree of home-range overlap, similar to Cavalcanti and Gese (2009) where 25 to $47 \%$ home-ranges of female jaguars overlapped during the dry season.
For males, individuals $M 7, M 8$ and $M 9$, were recorded in different aguadas in each of two consecutive years, which seems to suggest less fidelity to home-ranges than females, as found by Cavalcanti and Gese (2009). Our study also documented records of multiple males visiting the same aguada during the same year, which may suggest homerange overlap between males, a phenomenon that has been reported in other studies (De Azevedo and Murray 2007; Cavalcanti and Gese 2009; Harmsen et al. 2009).

Aguadas may represent regular sites of home-range overlap for jaguars considering the important resource they provide during the dry season, when they may become the only source of water used to cool off and to hunt down potential prey. In addition, Figel et al. (2019) have demonstrated that wetlands are keystone habitats for jaguars that increase their occupancy and detection probabilities. In 2016, the driest year in this study, aguada A4 was visited by six individuals (four females and two males), which may be related with the fact that A4 was the aguada that best maintained water levels across 4 study aguadas during that sampling season in the DLPB (García et al. 2018). Jaguar distribution is strongly influenced by availability of key resources (Sandell 1989), so the spatial distribution of aguadas may be an important landscape feature that influences the movements and interactions of individuals. Home-range overlap between conspecifics of the same sex has been reported to occur mainly outside core, high-quality areas, especially between females (De Azevedo and Murray 2007; Cavalcanti and Gese 2009); and the critical importance of aguadas in the JCU of the SM may rely in that these isolated water ponds are often the only surface water source available in this landscape, resulting that several individuals that use larger areas necessarily include these aguadas in their home-range. 

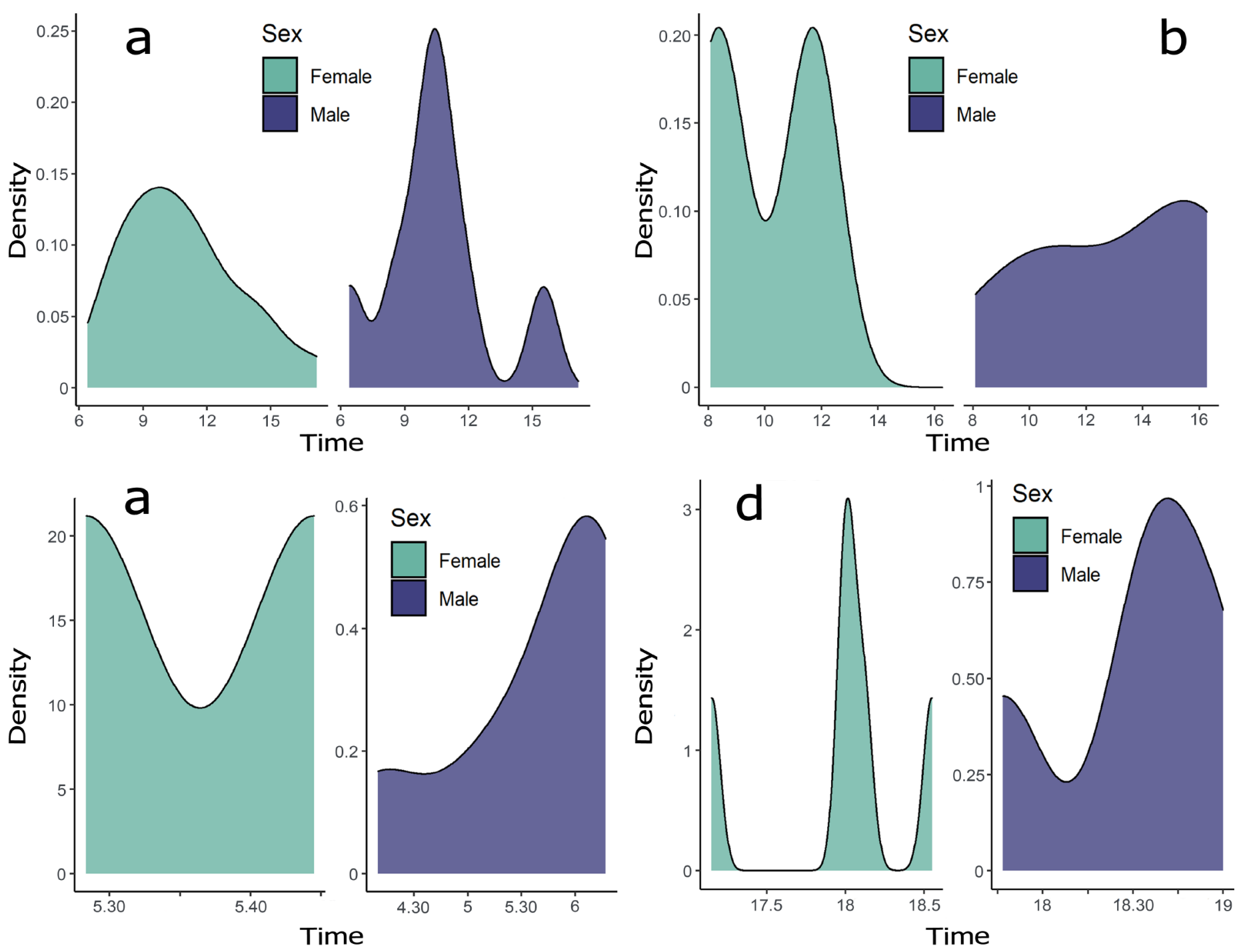

Figure 3. Activity patterns of female and male jaguars in aguadas. a: Diurnal activity. b: Nocturnal activity. c: Crepuscular activity during dawn. d: Crepuscular activity during dusk. Curves represent activity distribution density of jaguars at each data set of visit events ordered by sex. Curves were plotted using density function 'geom_density()' of package 'Ggplot2' in software R.

The number of jaguars identified in our study (14 individuals) is higher than previous studies within the MBR that used camera-traps installed on trails and roads (range 7 to 10 individuals), which may indicate the ecological importance of aguadas to jaguars and which has not been studied until now (Moreira et al. 2008; Moreira et al. 2009a; Moreira et al. 2009b; García-Anleu et al. 2015a; García-Anleu et al. 2015b).

Visitation rates (VR). According to Salom-Pérez et al. (2007), Conde et al. (2010) and Sollmann et al. (2011), female jaguars occupy smaller home-ranges, move less, and show different habitat use than males. Female jaguars do not move frequently on roads, trails, and open areas, and in previous studies, they have had lower camera-trap capture rates than males when cameras are installed near these spatial features (Salom-Pérez et al. 2007; Harmsen et al. 2010a). In contrast to this, our results showed that females in aguadas have higher capture rates compared to males, despite being represented by a smaller number of individuals ( 55.5 $\%$ of the males recorded). This suggests the use of aguadas is more frequent by females compared to males.
Srbek-Araujo (2018) suggests that the difference in capture rates between females and males reported in literature (higher for males and smaller for females) is probably due to the fact that females tend to avoid encounters with camera-traps deliberately. This behavior was not observed in this study. In fact, the individual with the highest number of detections was a female (F1) recorded in four different aguadas across three of the four years of study (Table 4). This indicates that instead of avoiding camera-traps specifically, female jaguars in other studies may be avoiding the habitat features where camera-traps are usually installed.

Activity patterns (AP). Jaguars exhibited primarily diurnal activity at aguadas; only $16 \%$ of records occurred at night (Jiménez et al. 2010). This data coincides with a report by González (2015) for jaguars and pumas Puma concolor (Linnaeus, 1771) in aguadas of the DLPB during the dry season 2013. According to Fedriana et al. (1999), Gliwicz and Dabrowski (2008), and Harmsen et al. (2010b), activity patterns of predators such as jaguars are associated with times of the day when their prey species are most vulnerable to preda- 


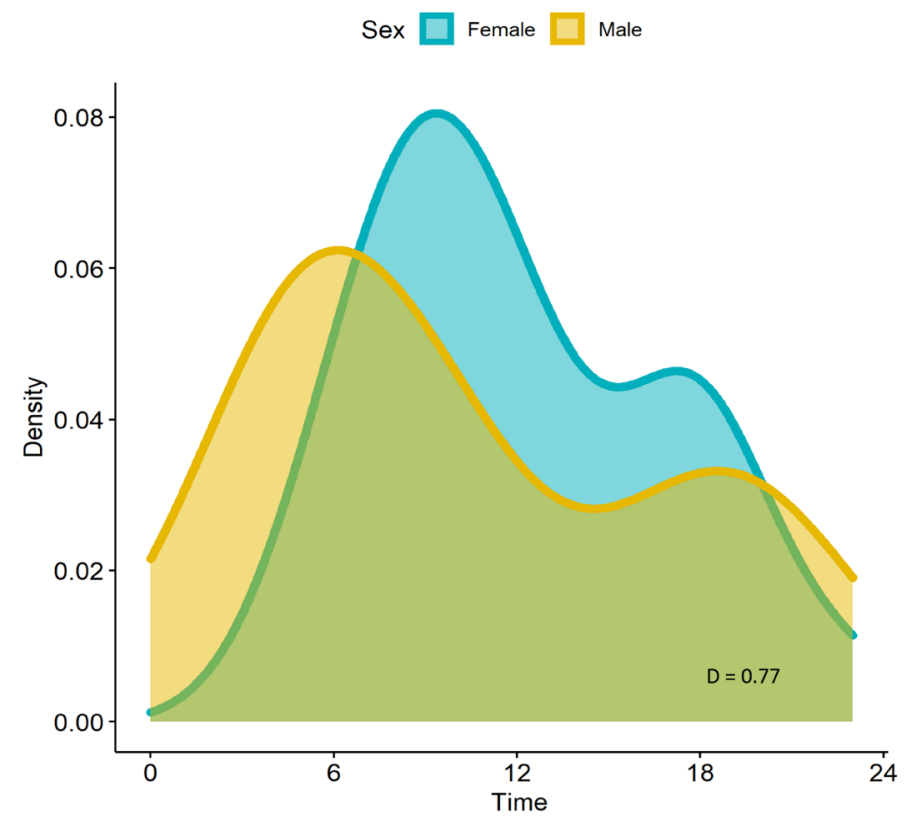

Figure 4. Proportion of overlap ( $D=0.77$, green area) in activity patterns of female and male jaguars in aguadas. Curves represent the bimodal distribution curves of activity density of female and male jaguars, calculated and plotted using packages 'Overlap' and 'Ggplot2' in software R.

tion. González (2015) reported that many potential prey species for jaguars that visit the aguadas of the DLPB are diurnal, including the great curassow Crax rubra Linnaeus, 1758, the crested guan Penelope purpurascens Wagler, 1830, the white-lipped peccary Tayassu pecari (Link, 1795), the collared peccary Pecari tajacu (Linnaeus, 1758), and the whitetailed deer Odocoileus virginianus (Zimmermann, 1780).

Although we did not find significant differences between female and male activity (Rowcliffe 2019), and that the level of overlap in activity revealed no significant differences (Meredith and Ridout 2020), sexes do differ in their peak hours of activity. Males visit the aguadas over a longer range of hours, as they have three peaks in activity. Activity of females in aguadas is concentrated primarily from mid-morning to mid-afternoon. Males showed the most activity just before and after dawn, while females showed the most activity just before and after noon; males had another peak of activity after dusk and a small peak around midday (Figure 3).

In a recent study, Sánchez-Pinzón et al. (2020) found that jaguar visitation to aguadas is significantly associated with the activity on these water ponds of the white-lipped peccary, one of its main prey (Aranda 1994; Estrada 2008). In this suggestion, sex of jaguars was not considered (Sánchez-Pinzón et al. 2020); so if female and male jaguar visitation patterns are also different as we suggest based on their different peak hours of activity in aguadas, preferred prey species may differ between males and females, as peak hours of activity of predators are strongly associated with peak hours of activity of their main prey (Fedriana et al. 1999; Gliwicz and Dabrowski 2008; Harmsen et al. 2010b).
Body mass in jaguars largely impacts their hunting decisions (Sunquist and Sunquist 2002), and it has been demonstrated that body mass among jaguar populations reflect the body mass of preferred prey species (Hoogesteijn and Mondolfi 1996). For Central American jaguars, which exhibit mean body mass differences between sexes [41.1 and $56.1 \mathrm{~kg}$ for females and males, respectively] (Hoogesteijn and Mondolfi 1996), differences in peak hours of activity among female and male jaguars from the same population may suggest that both sexes are preying on different prey, at different times. However, further investigation is required to identify sex-specific preferences of prey species within jaguar populations.

Sandoval-Lemus (2020) characterized the AP of Baird's tapir Tapirella bairdii (Gill, 1865) in aguadas of the DLPB, and found that tapirs increase their activity when temperature is high and tend to reduce it when humidity rises. He also found that tapirs tend to visit the aguadas more often during the dry season compared to the rainy season, and that use of the aguadas is negatively correlated with precipitation patterns, meaning that the number of days between visits tend to increase as rain increases. Sandoval-Lemus (2020) also found that tapirs are mainly nocturnal in aguadas (70\%), and its peaks of activity are during night at 21:00 and 02:00 $\mathrm{h}$. We only have sparse detections of female jaguars around these times and no detections of male jaguars but until before dawn (Figure 3b). Given this, it is possible that tapirs may be avoiding jaguars at aguadas of the DLPB, and additional research on the interaction of these two largest terrestrial mammals of the Neotropics, based on sex-specific and climatic variables at aguadas could yield interesting results (Sandoval-Lemus 2020).

This study suggests that aguadas are a limiting feature for jaguar home-ranges, and could elucidate unknown information about the habitat use of females. Despite the fact that this study did not contemplate a specific experimental design, given that its objectives were clearly descriptive, the information gathered and described reveals the frequency with which jaguars visit the bodies of water in a landscape where surface water is seasonally available, that the dynamics of use by females and males is also different, and the fact that many jaguars visit specific aguadas across multiple years. Additional research on this topic will provide invaluable information for efforts focused on the conservation and management of jaguar populations in the MBR and the SM.

Our data cannot be used for population estimates due to the design bias, as the aguadas are specific elements in the landscape that were not sampled randomly. Nonetheless, given that aguadas are a resource visited frequently by jaguars, the monitoring of aguadas and other bodies of water should be an important part of any population monitoring study and will prove useful to related research, such as jaguar collaring projects. For aguadas specific research, we recommend larger scale studies to extend this research to be able to compare visitation rates and activity patterns 
of jaguars in both the dry and rainy seasons, and in different landscapes features as roads and trails. Our results provide a baseline for such studies and provide data on capture rates and activity patterns that can be compared to more typical jaguar studies that tend to be done on trails and roads. In this sense, this study contributes to our overall understanding of jaguar behavior in different habitat types, information that can be useful for conservations purposes.

\section{Acknowledgments}

This study was carried out thanks to the co-financing of the Dirección General de Investigación (DIGI) of the San Carlos University of Guatemala [Digi projects (Budget Items 4.8.63.4.04 y 4.8.63.2.03) executed in 2016 and 2017], World Tapirs Conservation Program of the IUCN Tapir Specialist Group (TSG) and Fondation Segré through the Guatemala Baird's Tapir Conservation Program from Cecon and Defensores de la Naturaleza Foundation (FDN), and Jacksonville ZOO \& Gardens. We thank the institutions for sharing information of interest and logistical support: Consejo Nacional de Áreas Protegidas (Conap), Instituto de Antropología e Historia (Idaeh), R. Leonardo from FDN, and rangers from Protected Biotopos from Petén: A. Caal, E. Solís, E. Mayén, M. Ochaeta, R. Soto, S. Castillo, F. Neftalí, D. Aguirre, L. Rodas, J. Gutiérrez, J. Romero, H. Palacios, M. Rosales, B. Cruz, V. Hernández, C. Tzul, J. Morales, J. Najarro, M. Tobar, and M. Chun. We thank students of the School of Biology from San Carlos University: A. Porras, L. Núñez, S. Zetina, P. González, and M. G. Cajbon-Vivar. We also thank and really appreciate the effort of our friends T. Fish and C. A. Jordan for reviewing the English writing of this publication. To each and every one of them, our sincere thanks and appreciation.

\section{Literature cited}

Aranda, M. 1994. Importancia de los pecaríes (Tayassu spp.) en la alimentación del jaguar (Panthera onca). Acta Zoológica Mexicana 62:11-22.

Araujo, R. 2014. Programa municipal de desarrollo de gran visión para el municipio de Calakmul, Campeche (20132040). Guatemala: Deutsche Gesellschaft für Internationale Zusammenarbeit. Santa Elena, Guatemala.

Astate, S., R. Sollman, and L. Silvira. 2008. Comparative Ecology of Jaguars in Brazil. CAT News Special Issue 4:9-14.

Cavalcanti, S. M. C., and E. M. Gese. 2009. Spatial ecology and social interactions of jaguars (Panthera onca) in the southern Pantanal, Brazil. Journal of Mammalogy 90:935-945.

Consejo Nacional de Áreas Protegidas (Conap). 2015. Plan Maestro de la Reserva de la Biosfera Maya. Segunda Actualización. Guatemala, Guatemala.

Conde, D. A., F. Colchero, H. Zarza, N. L. Christensen, J. O. Sexton, C. Manterola, C. Chávez, A. Rivera, D. Azuara, and G. Ceballos. 2010. Sex matters: Modeling male and female habitat differences for jaguar conservation. Biological Conservation 143:1980-1988.

Currier, M. 1983. Felis concolor. Mammalian Species 200:1-7. De Azevedo, F. C. C., T. Gomes-De-Oliveira, C. R. De Paula, C. Bueno De Campos, E. A. Morales Jr, S. M. C. Cavalcanti, W.
Moraes, R. L. Pires, P. G. Crawshaw, B. de Mello, D. Alessio, K. M. Paschoaleeto, M. de Barros, and J. Polisar . 2016. Estatus del jaguar (Panthera onca) en Brasil. Pp. 366-433, in El jaguar en el siglo XXI: La perspectiva Continental (Medellín, R. A., J. A De la Torre, H. Zarza, C. Chávez, and G. Ceballos, eds.). Fondo de Cultura Económica, Universidad Nacional Autónoma de México. Ciudad de México, México.

De Azevedo, F. C. C., And D. L. Murray. 2007. Spatial organization and food habits of jaguars (Panthera onca) in a floodplain forest. Biological Conservation 137:391-402.

De La Torre, J. A., G. Ceballos, C. Chávez, H. Zarza, and R. A. Medellín. 2016. Prioridades y recomendaciones, ¿Cuáles son las necesidades para el jaguar en los próximos años? Pp. 495-505 in El jaguar en el siglo XXI: La perspectiva Continental (Medellín, R. A., J. A. De la Torre, H. Zarza, C. Chávez, and G. Ceballos, eds.). Fondo de Cultura Económica, Universidad Nacional Autónoma de México. Ciudad de México, México.

De La Torre, J. A., J. F. González-Maya, H. Zarza, G. Ceballos, AND R. A. MedelLín. 2017. The jaguar's spots are darker than they appear: assessing the global conservation status of the jaguar Panthera onca. Oryx 52:300-315.

De La Torre, J. A., M. Rivero, G. Camacho, L. A. Álvarez-Márquez, AND R. A. Medellín. 2019. First assessment of the conservation status of the jaguar Panthera onca in the Sierra Madre de Chiapas, Mexico. Oryx 53:192-195.

Di Bitetti, M. S., C. De Angelo, V. Quiroga, M. Altrichter, A. Paviolo, G. A. E. Cuyckens, and P. G. Perovic. 2016. Estado de conservación del jaguar en Argentina. Pp. 447-478, in El jaguar en el siglo XXI: La perspectiva Continental (Medellín, R. A., J. A. De la Torre, H. Zarza, C. Chávez, and G. Ceballos, eds.). Fondo de Cultura Económica, Universidad Nacional Autónoma de México. Ciudad de México, México.

Espinosa, S., L. Albuja, D. Tirira, G. Zapata-Ríos, E. Araguillin, V. Uteras, AND A. Noss. 2016. Análisis del estado de conservación del jaguar en el Ecuador. Pp. 320-339, in El jaguar en el siglo XXI: La perspectiva Continental (Medellín, R. A., J. A. De la Torre, H. Zarza, C. Chávez, and G. Ceballos, eds.). Fondo de Cultura Económica, Universidad Nacional Autónoma de México. Ciudad de México, México.

Estes, J. A., J. Terborgh, J. S. Brashares, M. E. Power, J. Berger, AND A. D. WardLE. 2011. Trophic Downgrading of Planet Earth. Science 333:301-306.

Estrada, C. 2008. Dieta, uso de hábitat y patrones de actividad del Puma (Puma concolor) y el jaguar (Panthera onca) en la Selva Maya, Centroamérica. Revista Mexicana de Mastozoología 12:113-130.

Fedriana, J., F. Palomares, and M. Delibes. 1999. Niche relations among three sympatric Mediterranean carnivores. Oecologia 121:138-148.

Figel, J. J., S. Botero-Cañola, G. Forero-Medina, J. D. SánchezLondoño, L. Valenzuela, and R. F. Noss. 2019. Wetlands are keystone habitats for jaguars in an intercontinental biodiversity hotspot. PLos One 14:e221705.

García, M. J., A. L. Aguilera, G. D. Guzmán-Flores, D. I. RodríGuez, AND V. R. González. 2018. Dinámica temporal de la disponibilidad de agua y microclima en aguadas del biotopo protegido Dos Lagunas, Petén, Guatemala. Ciencia, Tecnología y Salud 5:99-110. 
García-Anleu, R. A., G. Ponce-Santizo, A. Rodas, O. Cabrera, R. B. McNab, J. Polisar, AND M. LePe. 2015a. Jaguares y productores agropecuarios en la Zona de Amortiguamiento de la Reserva de Biosfera Maya, Guatemala: herramientas para mejorar la coexistencia. Pp. 139-149, in Conflictos entre felinos y humanos en América Latina (Castaño-Uribe, C., C. A. Lasso, R. Hoogesteijn, A. Diaz-Pulido, and E. Payán, eds.). Instituto Humboldt. Bogotá, Colombia.

García-Anleu, R. A., G. Ponce-Santizo, R. B. Mcnab, J. Polisar, A. Noss, J. Moreira, And G. Ruano. 2015b. The queen of Tikal and her suitors. CAT News 62 Spring 2015.

García-Anleu, R. A., R. B. McNab, J. Polisar, V. Ramos, J. Moreira, G. Ponce-Santizo, K. Duchez, R. Escobar, and A. Santos. 2016. Estado del Jaguar en Guatemala. Informe del 2013. Pp. 336443, in El jaguar en el siglo XXI: La perspectiva Continental (Medellín, R. A., J. A. De la Torre, H. Zarza, C. Chávez, and G. Ceballos, eds.). Fondo de Cultura Económica, Universidad Nacional Autónoma de México. Ciudad de México, México.

Gliwicz, J., AND M. DABrowskı. 2008. Ecological factors affecting the diel activity of voles in a multi-species community. Annales Zoologici Fennici 45:242-247.

GonzÁlez, V. R. 2015. Vertebrados medianos y mayores asociados a las aguadas del Biotopo Protegido Naachtún Dos Lagunas, Petén. Licentiate Thesis, San Carlos University of Guatemala, Guatemala, Guatemala.

Harmsen, B. J., R. Foster, S. C. Silver, L. E. Ostro, and C. P. DoncAster. 2009. Spatial and temporal interactions of sympatric jaguars (Panthera onca) and pumas (Puma concolor) in a neotropical forest. Journal of Mammalogy 90:612-620.

Harmsen, B. J., R. Foster, E. Sanchez, C. E. Gutiérrez-González, S. C. Silver, L. E. Ostro, M. Kelly, and H. Quigley. 2010a. Long term monitoring of jaguars in the Cockscomb Basin Wildlife Sanctuary, Belize; Implications for camera trap studies of carnivores. PLoS One 12:e0179505.

Harmsen, B.J., R. Foster, S. Silver, L. Ostro, and C. P. Doncaster. 2010b. Differential use of trails by forest mammals and the implications for camera-trap studies: a case study from Belize. Biotropica 42:126-133.

Hoogesteisn, R., And E. Mondolfi. 1996. Body mass and skull measurements in four jaguar populations and observations on their prey base. Bulletin Journal of the Florida Museum of Natural History 39:1,952-1,219.

Isasi-Catalá, E. 2013. Estado de conservación del jaguar (Panthera onca) en el Parque Nacional Guatopo, Venezuela: unidad prioritaria para su conservación. Pp. 95-102, in Grandes Felinos de Colombia. Vol. 1 (Payán, E., and C. Castaño-Uribe, eds.), Panthera Colombia, Fundación Herencia Ambiental Caribe and Cat Specialist Group IUCN/ SSC. Bogotá, Colombia.

Jędrzejewski, W., H. S. Robinson, M. Abarca, K. Zeller, G. Velasquez, E. A. D. Paemeleare, J. F. Goldberg., E. Payan, R. Hoogesteijn, E. O. Boede., K. Schmidt, M. Lampo., A. L. Viloria, R. Carreño, N. Robinson, P. M. Lukacs, J. J. Nowak., R. SalomPérez, F. Castañeda, V. Boron, and H. Quigley. 2018. Estimating large carnivore populations at global scale based on spatial predictions of density and distribution - Application to the jaguar (Panthera onca). PLoS One 13:e0194719.

Jiménez, C., H. Quintana, V. Pacheco, D. Melton, J. Torrealva, And G. Tello. 2010. Camera trap survey of medium and large mammals in a montane rainforest of northern Peru. Revista Peruana de Biología 17:191-196.

Karanth, K., AND J. Nichols. 1998. Estimation of tiger densities in India using photographic captures and recaptures. Ecology 79:2852-2862.

Maffei, L., D. Rumiz, R. Arispe, E. Cuéllar, and A. Noss. 2016. Situación del jaguar en Bolivia. Pp. 353-366, in El jaguar en el siglo XXI: La perspectiva Continental (Medellín, R. A., De la Torre, J. A, Zarza, H, Chávez, C, and G. Ceballos, eds.). Fondo de Cultura Económica, Universidad Nacional Autónoma de México. Ciudad de México, México.

McBride, R. T. JR., AND J. J. Thompson. 2018. Space use and movement of jaguar (Panthera onca) in western Paraguay. Mammalia 82:540-549.

Meredith, M., And M. Ridout. 2020. Package 'Overlap'. R package version 0.3.3. 1-20.

Mizutani, F., ANd P. Jewell. 1998. Home-range and movements of leopards (Panthera pardus) on a livestock ranch in Kenya. Journal of Zoology 244:269-286.

Monroy-Vilchis, O., M. Zarco-González, C. Rodríguez- Soto, L. SoriA-Díaz, AND V. URIos. 2011. Fototrampeo de mamíferos en la Sierra Nanchititla, México: Abundancia relativa y patrón de actividad. Revista de Biología Tropical 59:373-383

Morato, R. G., J. A. Stabach, C. H. Fleming, J. M. Calabrese, R. C. De Paula, K. M. P. Ferraz, D. L. Z. Kantek, S. S. Miyazaki, T. D. C. Pereira, G. R. Araujo, A. Paviolo, C. De Angelo, M. Di Bitetti, P. Cruz, F. Lima, L. Cullen, D. A. Sana, E. E. Ramalho, M. M. Carvalho, F. H. S. Soares, B. Zimbres, M. X. Silva, M. D. F. Moraes, A. Vogliotti, J. A. May JR, M. Haberfeld, L. Rampim, L. Sartorello, M. C. Ribeiro, and P. Leimgruber. 2016. Space use and Movement of a Neotropical Top Predator: The Endangered Jaguar. PLoS One 11:e0168176.

Moreira, J., R. McNab, R. García, and G. Ponce-Santizo. 2008. Densidad de jaguares en el Biotopo Protegido Dos Lagunas, Parque Nacional Mirador Rio Azul, Petén, Guatemala. Wildlife Conservation Society. Flores, Guatemala.

Moreira, J., R. García, R. McNab, G. Ponce-Santizo, M. Mérida, ADN G. Ruano. 2009a. Abundancia de jaguares y evaluación de presas asociadas al fototrampeo en las Concesiones Comunitarias del Bloque de Melchor de Mencos, Reserva de la Biósfera Maya, Petén, Guatemala. Wildlife Conservation Society. Flores, Guatemala.

Moreira, J., R. McNab, R. García, G. Ponce, M. Mérida, V. Méndez, M. Córdova, G. Ruano, K. Tut, H. Tut, F. Córdova, E. Muñoz, E. González, J. Cholom, and A. Xol. 2009b. Abundancia y densidad de jaguares en el Parque Nacional Laguna del Tigre-Corredor Biológico Central, Reserva de la Biósfera Maya. Wildlife Conservation Society. Flores, Guatemala.

Moreira, J., R. Garcia, R. McNab, G. Ruano, G. Ponce, M. Merida, K. Tut, P. Diaz, E. Gonzalez, M. Cordova, E. Centeno, C. Lopez, A. Vanegas, Y. Vanegas, F. Cordova, J. Kay, G. Polanco, and M. Barnes. 2011. Abundancia de jaguares y presas asociadas al fototrampeo en el sector oeste del Parque Nacional MiradorRio Azul, Reserva de Biosfera Maya. Wildlife Conservation Society. Flores, Guatemala.

Moreira, J., R. Garcia, R. McNab, G. Ruano, G. Ponce, M. Merida, K. Tut, P. Diaz, E. Gonzalez, M. Cordova, E. Centeno, C. Lopez, A. Vanegas, Y. Vanegas, F. Cordova, J. Kay, G. Polanco, and M. BARNES. 2011. Abundancia de jaguares y presas asociadas al 
fototrampeo en el sector oeste del Parque Nacional Mirador-Rio Azul, Reserva de Biosfera Maya. Wildlife Conservation Society. Flores, Guatemala.

Muckenhirn, N., AND L. Eisenberg. 1973. Home ranges and predation of the Ceylon leopard. Pp. 142-173, in The world's cats (Eaton, R. L., ed.). World Wildlife Safari. Winston, USA.

National Oceanic and Atmospheric Administration (NOAA). 2014. Solar Calculator of the National Oceanic \& Atmospheric Administration in Department of Commerce of the United States. $\quad$ http://www.esrl.noaa.gov/gmd/grad/solcalc/. Acceced on July 082019.

NúŃez, R., B. Miller, And F. Lindzey. 2002. Ecología del jaguar en la Reserva de la Biosfera Chamela-Cuixmala, Jalisco, México. Pp.107-126, in El jaguar en el Nuevo Mileno. Una evaluación de su estado, detección de prioridades y recomendaciones para la conservación de los jaguares en América (Medellín, R. A., C. Equihua, C. L. Chetkiewicz, P. G. Crawshaw, A. Rabinowitz, K. H. Redford, J. G. Robinson, E. W. Sanderson, and A. Taber, eds.). Universidad Nacional Autónoma de México, and Wildlife Conservation Society. México City, México.

Payán, E., C. Castaño-Uribe, J. F. González-Maya, C. Soto, C. Valderrama, M. Ruiz-García, and C. Soto. 2013. Distribución y estado de conservación del jaguar en Colombia. Pp. 23-36, in Grandes felinos de Colombia (Payán, E., and C. Castaño-Uribe, eds.). Panthera Colombia, Fundación Herencia Ambiental Caribe, Conservación Internacional Colombia, CAT Specialist Group IUCN-SSC. Bogotá, Colombia.

Pereira-Garbero, R., And A. Sappa. 2016. Historia del jaguar en Uruguay y la banda oriental. Pp. 336-443, in El jaguar en el siglo XXI: La perspectiva Continental (Medellín, R. A., De la Torre, J. A, Zarza, H, Chávez, C, and G. Ceballos, eds.). Fondo de Cultura Económica, Universidad Nacional Autónoma de México. Ciudad de México, México.

Rabelo, R. M., S. Aragón, and J. C. Bicca-Márquez. 2019. Prey abundance drives habitat occupancy by jaguars in Amazonian floodplain river islands. Acta Oecologica 97:28-33.

R Core Team. 2020. R: A Language and Environment for Statistical Computing. R Foundation 503 for Statistical Computing. Vienna, Austria.

Reyes, F. 2009. Los cuerpos de agua de la región Maya TikalYaxhá: Importancia de la vegetación acuática asociada, su conservación y el valor desde el uso humano. Centro de Datos para la Conservación, Centro de Estudios Conservacionistas, San Carlos University of Guatemala, Consejo Nacional de Ciencia y Tecnología. Guatemala, Guatemala.

Reyna-Hurtado, R., G. O'Farril, D. Simá, M. Andrade, A. Padilla, and L. SosA. 2010. Las aguadas de Calakmul: Reservorios de vida silvestre y de la riqueza natural de México. Biodiversitas 93:1-6.

Ridout, M. S., AND M. LinkiE. 2009. Estimating overlap of daily activity patterns from camera trap data. Journal of Agricultural, Biological and Environmental Statistics 14:32-337.

Rowcliffe, M. 2019. Package 'Activity': Animal Activity Statistics. R package version 1.3. 1-22.

Salom-Pérez, R., E. Carrillo, J. C. Sáenz, and J. M. Mora. 2007. Critical condition of the jaguar Panthera onca population in Corcovado National Park, Costa Rica. Oryx 41:51-56.

Sánchez-Pinzón, K., R. Reyna-Hurtado, E. Naranjo, and A. Keuroghlian. 2020. Peccaries and their relation with water availability and their predators in Calakmul, México. Therya 11:213-220.
Sandell, M. 1989. The mating tactics and spacing patterns of solitary carnivores. Pp. 164-182, in Carnivore behavior, ecology, and evolution (Gittleman J. L., ed.). Springer. Boston, U.S.A.

Sandoval-Lemus, M. A. 2020. Caracterización del patrón de actividad del tapir centroamericano (Tapirus bairdii) en aguadas del Biotopo Protegido Dos Lagunas, Reserva de Biosfera Maya. Licentiate Thesis, San Carlos University of Guatemala. Guatemala, Guatemala.

Schaller, G. B., and P. Crawshaw Jr. 1980. Movement patterns of jaguar. Biotropica 12:161-168.

Scognamillo, D., I. Maxit, M. Sunquist, and L. Farrell. 2002. Ecología del jaguar y el problema de la depredación de ganado en un hato de los Llanos venezolanos. Pp. 139150, in El jaguar en el nuevo mileno. Una evaluación de su estado, detección de prioridades y recomendaciones para la conservación de los jaguares en América (Medellín, R. A., C. Equihua, C. L. Chetkiewicz, P. G. Crawshaw, A. Rabinowitz, K. H. Redford, J. G. Robinson, E. W. Sanderson, and A. Taber, eds.). Universidad Nacional Autónoma de México, and Wildlife Conservation Society. México City, México.

Seymour, K. L. 1989. Panthera onca. Mammalian Species 340:1-9. Simá, D., O. Retana, R. Reyna, and J. Miranda. 2008. Detección de fauna silvestre mediante el sistema de fototrampeo en dos ampliaciones forestales de la reserva de la Biosfera de Calakmul, Campeche, México. Reserva de Biósfera Calakmul, ProNatura Península de Yucatán, The Nature Conservancy, Universidad Autónoma de Campeche, and Florida University. Ciudad de México, México.

Sollmann, R., M. M. Furtado, B. Gardner, H. Hofer, A. Jacomo, N. M. TôRRES, N, AND L. Silveira. 2011. Improving density estimates for elusive carnivores: accounting for sex-specific detection and movements using spatial capture-recapture models for jaguars in central Brazil. Biological Conservation 144:1017-1024.

Srbeck-araujo, A. C. 2018. Do female jaguars (Panthera onca Linneus, 1758) deliberately avoid camera traps? Mammalian Biology 88:26-30.

Sunquist, M. E. 1981. The social organization of tigers in Royal Chitawan National Park, Nepal. Smithsonian Contributions to Zoology 336:1-98.

Sunquist, M., And F. Sunquist. 2002. The essence of cats. Pp. 11-13, in Wild cats of the world (Sunquist, M., and F. Sunquist, eds.). University of Chicago Press. Chicago, U.S.A.

Tobler, M. 2015. Camera Base, User Guide. Version 1.7 On line. http://www.atrium-biodiversity.org/tools/camerabase/files/ CameraBaseDoc1.7.pdf. Acceced on August 252019.

Veras, E. 2009. Diagnóstico de la situación actual de las áreas protegidas que co-administra la Universidad de San Carlos de Guatemala y propuesta de lineamientos estratégicos para su sostenibilidad. Dirección General de Investigación, San Carlos University of Guatemala. Guatemala, Guatemala.

Zeller, K. 2007. Jaguars in the New Millennium Data Base Update: The State of the Jaguar in 2006. Wildlife Conservation Society-Jaguar Conservation Program. New York, U.S.A.

Associated editor: Rafael Avila Flores

Submitted: August 10, 2019; Reviewed: September 19, 2019;

Accepted: June 15, 2020; Published on line: July 30, 2020. 
56 THERYA Vol. 12 (1): 45-55 